\title{
Crystal structure and phase transition in the compound
}

$$
\left[\mathrm{C}_{6} \mathrm{H}_{17} \mathrm{~N}_{3}\right] \mathrm{TIC}_{15 .} 2 \mathrm{H}_{2} \mathrm{O}
$$

HibaKhili $^{\mathrm{a}}$, Najla Chaari ${ }^{\mathrm{a}}$, Abdelaziz Koumina ${ }^{\mathrm{b}}$, Slaheddine Chaabouni ${ }^{\mathrm{a}}$.

${ }^{a}$ Laboratoire des Sciences des Matériaux et de l'Environnement, département de chimie, Faculté des Sciences de Sfax, BP 1171, 3018 Sfax, Tunisia.

E-mail address: Kh.Hiba@hotmail.com; n_chaari2003@yahoo.fr; chaabouni_slaheddine@yahoo.fr.

${ }^{\mathrm{b}}$ ENS de Marrakech, Département de physique, Université Cadi-Ayyad Marrakech, Morocco.

E-mail address: koumina@gmail.com.

\section{Abstract}

The title compound 1-(2-ammonium-ethyl) piperaziniumpentachlorothallate (III) dihydrate crystallizes in the monoclinic system with space group $\mathrm{Cm}$. The unit cell dimensions are: $\mathrm{a}=12.786(5), b=12.021(5), c=10.566(5) \AA$, $\beta=$ $93.469(5)^{\circ}{ }^{\circ}$, with $Z=4$. Its crystal structure was determined and refined down to $R=0.045$. The structure of this compound consists of 1-(2-ammonium-éthyl) pipéraziniumcations and $\left[\mathrm{Tl}_{2} \mathrm{Cl}_{10}\right]^{4-}$ dimers. The arylammoniumcations are located between anions and connected to the halogen atoms by $\mathrm{N}-\mathrm{H}$... Cl hydrogen bonds. One phase transition at $\mathrm{T}=$ $320 \mathrm{~K}$ is detected and studied by differential scanning calorimetry, dielectric and impedance spectroscopy measurements. The evolution of the dielectric constant and dissipation factor as a function of temperature revealed the transition characterized by a strong jump in the conductivity plot.

\section{Keywords:}

Organic-inorganic hybrid material; Crystal structure; Halogenothallates(III). *Corresponding author: Hiba Khili.

Tel: +21698813420, fax +21674274437

E-mail address: kh.hiba@hotmail.com

Address: Route de Soukra km 3.5 - B.P. n 1171 - 3000 Sfax.

\section{Council for Innovative Research}

Peer Review Research Publishing System

\section{Journal: Journal of Advances in Chemistry}

Vol. 8, No. 1

editor@cirworld.com 


\section{Introduction}

A large number of inorganic thallium (III) complexes are presently known anda systematic survey of their main crystallographic data has been reported $[1,2]$. Thallium complexes exhibit a wide range of coordination numbers and geometries (tetrahedral $[4,5,6]$, square pyramidal $[6,7]$, trigonalbipyramid $[3,5]$, octahedral $[5,7])$ and the empirical formula of the complex is not always a reliable indicator for its structure. Some of these compounds exhibit structural phase transitions and interesting physical properties such as ferroelectricity and ionic conduction [8, 9].

Recently, the research of organic-inorganic polar crystals is very important for quadratic nonlinear optical phenomena which are, today, oriented to the organic aromatic cations containing $\pi$-electrons systems asymmetrized by electron donor and/or accepted substitutes.

The second is devoted to the ionic hostmatrices that may increase the packing cohesion built up through ionic, hydrogen bonding often by underlying of a more important resistance in organic-inorganic polar crystals than in purely organic polar materials. Taking these considerations into account, we report and discuss the results of investigations, concerning a new compound $\left[\mathrm{C}_{6} \mathrm{H}_{17} \mathrm{~N}_{3}\right] \mathrm{TICl}_{5}$. $2 \mathrm{H}_{2} \mathrm{O}$. We have performed X-ray diffraction measurements providing us information about the complete crystal structure at room temperature. This structural study is accompanied by calorimetric, dielectric and impedance spectroscopy measurements.

\section{Experimental section}

\section{II.1. Crystal chemistry}

1-(2-ammonium-éthyl) piperaziniumpentachlorothallate (III) dihydrate crystals were obtained by dissolving the appropriate amine and $\mathrm{Tl}_{2} \mathrm{O}_{3}$ in a minimum volume of concentrated hydrochloric acid, warming as necessary. After several weeks of evaporation, parallelepiped shaped monocrystals were obtained and these were isolated by filtration and dried in a vacuum desiccator. The chemical analysis of thallium atoms and chloride anions has been carried out [10]. Density was measured at room temperature by flotation in $\mathrm{CCl}_{4}$. It is noted that the compound is stable in air and its formula is determined by chemical analysis and confirmed by refinement of the crystal structure. The average value of density, $D m=2.211 \mathrm{~g} \mathrm{~cm}^{-3}$, is in agreement with that calculated, $D x=2.198 \mathrm{~g} \mathrm{~cm}^{-3}$. The cell contains four formula units of $\left[\mathrm{C}_{6} \mathrm{H}_{17} \mathrm{~N}_{3}\right] \mathrm{TICl}_{5} .2 \mathrm{H}_{2} \mathrm{O}$.

\section{II.2. Crystal structure}

The single crystal study was performed by using a four-circle Bruker APEXII CCD diffractometer. The main crystal data, the parameters used for intensity data collection and the reliability factors are summarized in Table 1 . The crystal structure was carried out with a Patterson method using SHELXS-86 [11] which allowed the localization of thallium and chlorine atoms.

All the other atoms were located after subsequent cycles of refinement and difference-Fourier syntheses by using SHELXL-97 [12]. All H-atoms positions could be determined from the difference Fourier map. However, the calculated positions at a distance of 0.96 were used in the final refinement, with a common isotropic displacement parameter, since the calculated distances were more reasonable than the refined ones. Full matrix refinement with anisotropic thermal parameters for all non hydrogen atoms and isotropic thermal parameters for $\mathrm{H}$ atoms converged to a final $R$ value of 0.045 . 
Table 1. Summary of physical constants and parameters associated with data collection and structure refinement

\begin{tabular}{|c|c|}
\hline Compound & 1-(2-ammonium-ethyl) piperaziniumpentachlorothallate (III ) dihydrate \\
\hline Formula & {$\left[\mathrm{C}_{6} \mathrm{H}_{17} \mathrm{~N}_{3}\right] \mathrm{TICl}_{5} .2 \mathrm{H}_{2} \mathrm{O}$} \\
\hline Color/shape & Colorless/parallelepiped \\
\hline System & Monoclinic \\
\hline Space group & $\mathrm{Cm}$ \\
\hline Temperature $\left({ }^{\circ} \mathrm{C}\right)$ & 25 \\
\hline \multicolumn{2}{|l|}{ Cell constants } \\
\hline$a\left(A^{\circ}\right)$ & $12.786(5)$ \\
\hline$b\left(A^{\circ}\right)$ & $12.021(5)$ \\
\hline$c\left(A^{\circ}\right)$ & $10.566(5)$ \\
\hline$\beta\left({ }^{\circ}\right)$ & $93.469(5)$ \\
\hline Cell volume $\left(A^{\circ}{ }^{3}\right)$ & $1621.0(1)$ \\
\hline Formula units/unit cell & 4 \\
\hline Formula weight & 1627.12 \\
\hline Dcalcd $\left(\mathrm{g} \mathrm{cm}^{-3}\right)$ & 2.198 \\
\hline Dobs $\left(\mathrm{g} \mathrm{cm}^{-3}\right)$ & 2.211 \\
\hline Diffractometer/scan & Bruker APEXII CCD \\
\hline Radiation, graphite & $\operatorname{Mo~Ka~}\left(\mathrm{k}=0.71073 \mathrm{~A}^{\circ}\right)$ \\
\hline monochromator & \\
\hline Crystal dimensions (mm) & $0.01 \times 0.02 \times 0.03$ \\
\hline Absorption & Numerical \\
\hline$\mu$ calcd $\left(\mathrm{mm}^{-1}\right)$ & 35.27 \\
\hline Unique reflections & 1302 \\
\hline$\theta$ range $(\mathrm{deg})$ & $3.5 \leq \theta \leq 35^{\circ}$ \\
\hline Reflections with I $>4 \sigma(\mathrm{Fo})$ & 1222 \\
\hline Range of $h, k, I$ & $\pm 11, \pm 10, \pm 9$ \\
\hline$F(000)$ & 1680.0 \\
\hline $\mathrm{R}=\Sigma|| \mathrm{F}_{\mathrm{o}}|-| \mathrm{F}_{\mathrm{c}}|V \Sigma| \mathrm{F}_{\mathrm{o}} \mid$ & 0.045 \\
\hline $\mathrm{Rw}$ & 0.051 \\
\hline Number of parameters & 164 \\
\hline Computer programs & SHELXS [10], SHELXL [11] \\
\hline
\end{tabular}

The final atomic coordinates are given in Table 2. Main geometrical features, bond distances and angles are reported in Table 3. Hydrogen bonding parameters are reported in Table 4.

\section{II.3. Calorimetric measurements}

DSC experiments were performed on heating the 1-(2-ammonium-ethyl) piperaziniumpentachlorothallate (III) dihydrate from $193 \mathrm{~K}$ to $373 \mathrm{~K}$. The DSC measurements were performed with the heating/cooling rates at a heating rate of $5 \mathrm{~K} \cdot \mathrm{min}^{-1}$ 


\section{II.4. Electrical measurements}

Crystals of $\left[\mathrm{C}_{6} \mathrm{H}_{17} \mathrm{~N}_{3}\right] \mathrm{TICl}_{5} .2 \mathrm{H}_{2} \mathrm{O}$ were crushed and pressed to dense and translucent pellets (8mm in diameter ; $2 \mathrm{~mm}$ in thickness) at a pressure of $200 \mathrm{MPa}$. Both planar faces of these pellets were coated with silver paint and the pellets were then sandwiched between metal electrodes, which were also coated with silver paint. Electrical properties were determined by impedance method using a frequency response analyzer Novocontrol BDS 400 . The frequency range was $1 \mathrm{~Hz}-1 \mathrm{MHz}$ and the measurements were carried out in vacuum between 298 and $413 \mathrm{~K}$. The sample temperature was stabilized at $\pm 5^{\circ} \mathrm{C}$.

\section{Result and discussions}

\section{III.1. Crystallography study}

$\left[\mathrm{C}_{6} \mathrm{H}_{17} \mathrm{~N}_{3}\right] \mathrm{TICl}_{5} .2 \mathrm{H}_{2} \mathrm{O}$ belongs to a monoclinic $\mathrm{Cm}$ space group at $298 \mathrm{~K}$. The structural study of the compound $\left[\mathrm{C}_{6} \mathrm{H}_{15} \mathrm{~N}_{3}\right] \mathrm{TICl}_{5} .2 \mathrm{H}_{2} \mathrm{O}$ revealed that the coordination polyhedra of thallium is formed by association of two octahedral sharing two chlorine vertices (an edge) forming dimers along the a axis. These dimers are arranged around $z=0$.

A projection along the $b$ axis of the atomic arrangement of $\left[\mathrm{C}_{6} \mathrm{H}_{17} \mathrm{~N}_{3}\right] \mathrm{TICl}$. $2 \mathrm{H}_{2} \mathrm{O}$ is depicted in Figure 1. The structure of the title compound consists of $\left[\mathrm{Tl}_{2} \mathrm{Cl}_{10}\right]^{4-}$ dimer anions and biprotonated 1-(2ammonium-ethyl) piperaziniumcations, the $\mathrm{TICl}_{6}{ }^{3-}$ configuration is a slightly distorted octahedron.

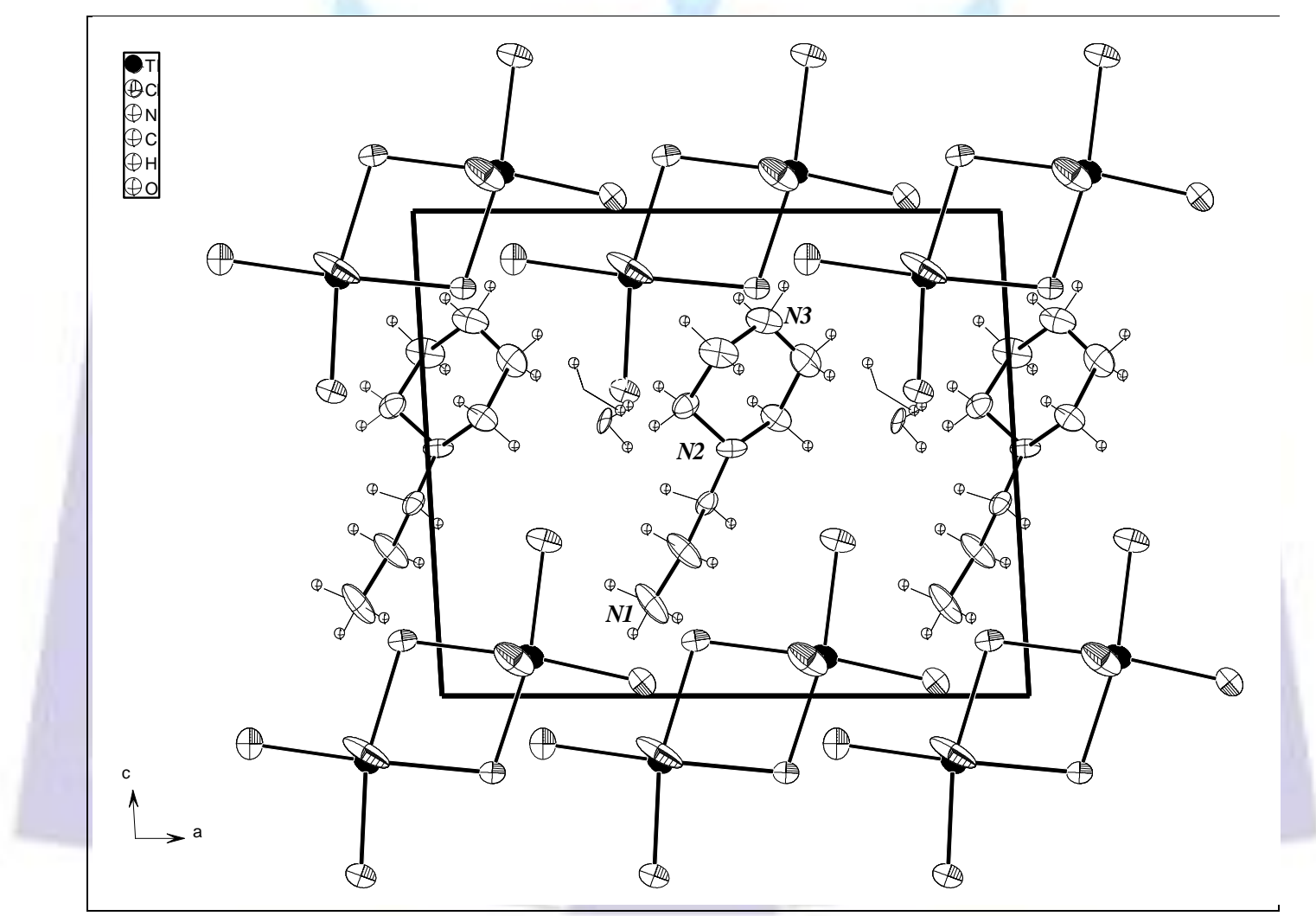

Fig1: Projection of $\left[\mathrm{C}_{6} \mathrm{H}_{17} \mathrm{~N}_{3}\right] \mathrm{TICl}_{5}, 2 \mathrm{H}_{2} \mathrm{O}$ structure in the $(\mathrm{a}, \mathrm{c})$ plane.

Each thallium ion is surrounded by six chlorine ions and the $\mathrm{TI}-\mathrm{Cl}$ bond lengths ranging from 2.392(1) to 2.806(2) $\AA$ A. The angles involving mutually cis ions range from $78.6(4)$ to $98.4(5)^{\circ}$, while the trans angles vary from $164.2(4)$ to $176.9(6)^{\circ}$.

The deviations of these bond angles from the ideal values of $90^{\circ}$ and $180^{\circ}$ are consistent with the presence of the long bonds, the largest deviations from $90^{\circ}$ involving the most weakly bonded chlorine ions, $\mathrm{Cl} 3-\mathrm{Tl} 1-\mathrm{Cl} 4=79.2(4)^{\circ}$, $\mathrm{Cl} 3-\mathrm{Tl} 2-\mathrm{Cl} 4=78.6(4)^{\circ}, \mathrm{Cl} 4-\mathrm{Tl} 1-\mathrm{Cl} 7=82.4(2)^{\circ}$. Table 3 reports the main geometrical features of 1-(2 ammonium-ethyl) piperazinium entities. The organic groups are located in the $(\mathrm{a}, \mathrm{c})$ plane aroundz $=0.5$.

The C-N bond lengths vary from $1.37(3)$ to $1.50(4) \AA$. The $C-C$ bond lengths vary from $1.51(3)$ to $1.63(4) \AA$. They are in agreement with those found in the related compounds [13-14]. The C-C perpendicular interplanar distances range from 6.397(3) $\AA$ and 6.963(3) $\AA$, indicating the existence of Van der Waals interactions between $\left[\mathrm{C}_{6} \mathrm{H}_{17} \mathrm{~N}_{3}\right]^{+}$cations. 
Table 2. The final atomic coordinates

\begin{tabular}{|c|c|c|c|c|}
\hline Atoms & $\mathrm{X} / \mathrm{a}$ & $\mathrm{Y} / \mathrm{b}$ & $Z / c$ & $U_{\text {éq }}$ or $U_{\text {iso }}{ }^{*}$ \\
\hline TI1 & $0.1521(3)$ & 0.0000 & $0.0836(3)$ & 0.0384 \\
\hline TI2 & $-0.1381(3)$ & 0.0000 & $-0.1322(3)$ & 0.0354 \\
\hline $\mathrm{Cl} 1$ & $0.3406(1)$ & 0.0000 & $0.0316(1)$ & 0.0785 \\
\hline $\mathrm{Cl} 2$ & $0.1884(1)$ & 0.0000 & $0.3234(1)$ & 0.0419 \\
\hline $\mathrm{Cl} 3$ & $0.0761(1)$ & 0.0000 & $-0.1564(1)$ & 0.0491 \\
\hline $\mathrm{Cl} 4$ & $-0.0639(1)$ & 0.0000 & $0.1168(1)$ & 0.0363 \\
\hline $\mathrm{Cl} 5$ & $-0.1591(1)$ & 0.0000 & $-0.3690(1)$ & 0.0401 \\
\hline $\mathrm{Cl} 6$ & $-0.3350(1)$ & 0.0000 & $-0.0968(2)$ & 0.0948 \\
\hline $\mathrm{Cl} 7$ & $0.1248(7)$ & $0.2099(8)$ & $0.0779(1)$ & 0.0595 \\
\hline $\mathrm{Cl} 8$ & $-0.1371(8)$ & $0.1984(8)$ & $-0.1148(1)$ & 0.0665 \\
\hline $\mathrm{N} 1$ & $0.3653(2)$ & $0.266(2)$ & $0.193(2)$ & 0.0606 \\
\hline $\mathrm{C} 1$ & $0.426(2)$ & $0.212(2)$ & $0.302(3)$ & 0.0539 \\
\hline $\mathrm{C} 2$ & $0.4690(2)$ & $0.295(2)$ & $0.400(2)$ & 0.0258 \\
\hline N2 & $0.5172(2)$ & $0.2412(1)$ & $0.5134(1)$ & 0.0248 \\
\hline $\mathrm{C} 3$ & $0.596(2)$ & $0.3241(2)$ & $0.576(2)$ & 0.0353 \\
\hline $\mathrm{C} 4$ & $0.652(2)$ & $0.256(2)$ & $0.694(3)$ & 0.0420 \\
\hline N3 & $0.5856(2)$ & $0.2103(2)$ & $0.7765(2)$ & 0.0423 \\
\hline C5 & $0.505(2)$ & $0.1352(2)$ & $0.710(2)$ & 0.0421 \\
\hline C6 & $0.4432(2)$ & $0.1982(2)$ & $0.601(2)$ & 0.0323 \\
\hline 01 & $0.7709(1)$ & 0.5000 & $0.6347(1)$ & 0.0094 \\
\hline $\mathrm{O} 2$ & $0.8037(1)$ & $0.328(2)$ & $0.5700(1)$ & 0.0912 \\
\hline $\mathrm{H} 1-1$ & 0.3332 & 0.2254 & 0.1275 & 0.0824 \\
\hline $\mathrm{H} 1-2$ & 0.4105 & 0.3312 & 0.1591 & 0.0824 \\
\hline $\mathrm{H} 1-3$ & 0.2999 & 0.3204 & 0.2279 & 0.0824 \\
\hline $\mathrm{H} 11$ & 0.3673 & 0.1675 & 0.3428 & 0.0660 \\
\hline $\mathrm{H} 12$ & 0.4755 & 0.1686 & 0.2728 & 0.0660 \\
\hline $\mathrm{H} 21$ & 0.5118 & 0.3443 & 0.3536 & 0.0341 \\
\hline H22 & 0.4043 & 0.3415 & 0.4252 & 0.0341 \\
\hline H31 & 0.6504 & 0.3473 & 0.5144 & 0.0438 \\
\hline H32 & 0.5613 & 0.3924 & 0.6061 & 0.0438 \\
\hline $\mathrm{H} 41$ & 0.7019 & 0.3064 & 0.7440 & 0.0498 \\
\hline $\mathrm{H} 42$ & 0.6943 & 0.1926 & 0.6596 & 0.0498 \\
\hline H3-1 & 0.6263 & 0.1660 & 0.8430 & 0.0511 \\
\hline H3-2 & 0.5481 & 0.2722 & 0.8187 & 0.0511 \\
\hline $\mathrm{H} 51$ & 0.4544 & 0.1070 & 0.7709 & 0.0531 \\
\hline H52 & 0.5410 & 0.0699 & 0.6716 & 0.0531 \\
\hline $\mathrm{H} 61$ & 0.4029 & 0.2616 & 0.6370 & 0.0411 \\
\hline $\mathrm{H} 62$ & 0.3913 & 0.1467 & 0.5548 & 0.0411 \\
\hline $\mathrm{H} 1 \mathrm{~W} 1$ & 0.7608 & 0.5697 & 0.6844 & 0.0149 \\
\hline H1W2 & 0.8355 & 0.5000 & 0.5867 & 0.0149 \\
\hline $\mathrm{H} 2 \mathrm{~W} 1$ & 0.8482 & 0.3934 & 0.5974 & 0.1078 \\
\hline H2W2 & 0.8438 & 0.2807 & 0.5111 & 0.1078 \\
\hline
\end{tabular}


Table 3. Main interatomic distances $(\AA)$ and bond angles (deg) in $\left[\mathrm{C}_{6} \mathrm{H}_{17} \mathrm{~N}_{3}\right] \mathrm{TICl}_{5} .2 \mathrm{H}_{2} \mathrm{O}$.

\begin{tabular}{cccc}
\hline \multicolumn{5}{c}{ Organic group } \\
\hline N3 - C4 & $1.37(3)$ & C4-N3-C3 & $112.1(2)$ \\
N3 - C5 & $1.51(3)$ & N2-C3-C4 & $104.5(2)$ \\
C3 - N2 & $1.54(3)$ & C3-N2-C6 & $113.2(2)$ \\
C3 - C4 & $1.63(4)$ & C3-N2-C2 & $107.5(1)$ \\
N2 - C6 & $1.46(3)$ & C6-N2-C2 & $114.7(2)$ \\
N2-C2 & $1.47(3)$ & C3-C4-N3 & $115(2)$ \\
C5-C6 & $1.56(3)$ & N3-C3-C6 & $110.9(2)$ \\
C1-N1 & $1.50(4)$ & C3-C6-N2 & $108.6(2)$ \\
C1-C2 & $1.51(3)$ & N1-C1-C2 & $112(2)$ \\
O1-H1W1 & 1.002 & C1-C2-N2 & $112.5(2)$ \\
O1-H1W2 & 0.994 & & \\
O2-H2W1 & 1.003 & & \\
O2-H2W2 & 1.006 & & \\
\hline
\end{tabular}

$\left[\mathrm{TICl}_{6}\right]^{3-}$ octahedron 1

\begin{tabular}{lllllll}
\hline Tl1 & $C l 1$ & $C l 2$ & $C l 3$ & $C l 4$ & $C l 7$ & $C / 7$ \\
$C l 1$ & $2.504(2)$ & $3.748(7)$ & $3.974(9)$ & $5.374(7)$ & $3.655(7)$ & $3.655(7)$ \\
$C l 2$ & $95.7(5)$ & $2.548(2)$ & $5.192(7)$ & $3.691(8)$ & $3.622(6)$ & $3.6227)$ \\
$C / 3$ & $95.3(5)$ & $169.1(5)$ & $2.661(2)$ & $3.535(9)$ & $3.617(6)$ & $3.617(6)$ \\
$C l 4$ & $174.5(5)$ & $89.8(5)$ & $79.2(4)$ & $2.806(2)$ & $3.705(8)$ & $3.705(1)$ \\
$C l 7$ & $97.3(2)$ & $92.3(3)$ & $86.3(3)$ & $82.4(2)$ & $2.548(2)$ & $5.027(6)$ \\
$C l 7$ & $97.3(2)$ & $92.3(3)$ & $86.3(3)$ & $82.4(2)$ & $164.2(4)$ & $2.548(1)$ \\
\hline
\end{tabular}

$\left[\mathrm{TICl}_{6}\right]^{3-}$ octahedron2

\begin{tabular}{lllllll}
\hline Tl2 & $C / 3$ & $C l 4$ & $C / 5$ & $C l 6$ & $C / 8$ & $C / 8^{\prime}$ \\
$C / 3$ & $2.766(2)$ & $3.535(7)$ & $3.695(1)$ & $5.318(7)$ & $3.524(7)$ & $3.524(8)$ \\
$C / 4$ & $78.6(4)$ & $2.742(2)$ & $5.231(7)$ & $3.912(7)$ & $3.506(7)$ & $3.506(7)$ \\
$C / 5$ & $87.4(5)$ & $166.0(4)$ & $2.500(2)$ & $3.783(7)$ & $3.644(7)$ & $3.644(7)$ \\
$C l 6$ & $176.9(6)$ & $98.4(5)$ & $95.7(5)$ & $2.568(2)$ & $3.690(8)$ & $3.690(9)$ \\
$C l 8$ & $90.4(3)$ & $85.8(3)$ & $94.4(3)$ & $89.4(3)$ & $2.392(1)$ & $4.870(7)$ \\
$C l 8^{\prime}$ & $90.4(3)$ & $85.8(3)$ & $94.4(3)$ & $89.4(3)$ & $171.2(6)$ & $2.392(1)$ \\
\hline
\end{tabular}

The intermolecular hydrogen bonding contacts $\mathrm{N}-\mathrm{H}---\mathrm{Cl}$ provide a linkage between the $\left[\mathrm{C}_{6} \mathrm{H}_{17} \mathrm{~N}_{3}\right]^{2+}$ entities and the $\left[\mathrm{Tl}_{2} \mathrm{Cl}_{10}\right]^{4-}$ anions figure 2 .

The hydrogen bonds give rise to a three-dimensional construction of the structure and add stability to this compound. 
Table 4. Hydrogen bonding parameters for $\left[\mathrm{C}_{6} \mathrm{H}_{15} \mathrm{~N}_{3}\right] \mathrm{TICl}_{5} .2 \mathrm{H}_{2} \mathrm{O}$

\begin{tabular}{ccccc}
\hline $\mathrm{N}-\mathrm{H} \ldots \mathrm{Cl}$ & $\mathrm{d}(\mathrm{D}-\mathrm{H})$ & $\mathrm{d}(\mathrm{H} . . \mathrm{A})$ & $<\mathrm{DHA}$ & $\mathrm{d}(\mathrm{D} \ldots \mathrm{A})$ \\
\hline $\mathrm{N} 1-\mathrm{H} 1-1 \ldots \mathrm{Cl} 1$ & $0.923(2)$ & $2.896(5)$ & $137.29(1)$ & $3.629(2)$ \\
$\mathrm{N} 1-\mathrm{H} 1-1 \ldots \mathrm{Cl}$ & $0.923(2)$ & $2.691(9)$ & $124.96(1)$ & $3.307(3)$ \\
$\mathrm{N} 1-\mathrm{H} 1-1 \ldots \mathrm{Cl}^{(\mathrm{a})}$ & $0.923(2)$ & $2.767(1)$ & $116.05(1)$ & $3.279(2)$ \\
$\mathrm{N} 1-\mathrm{H} 1-2 \ldots \mathrm{Cl} 4^{(\mathrm{b})}$ & $1.05(2)$ & $2.108(4)$ & $152.51(1)$ & $3.077(3)$ \\
$\mathrm{N} 1-\mathrm{H} 1-2 \ldots \mathrm{Cl} 7^{(\mathrm{b})}$ & $1.05(2)$ & $2.962(1)$ & $120.83(1)$ & $3.614(3)$ \\
$\mathrm{N} 1-\mathrm{H} 1-2 \ldots \mathrm{Cl} 8^{(\mathrm{a})}$ & $1.05(2)$ & $2.943(1)$ & $99.2(1)$ & $3.279(2)$ \\
$\mathrm{N} 1-\mathrm{H} 1-3 \ldots \mathrm{Cl} 4^{(\mathrm{b})}$ & $1.14(2)$ & $3.053(1)$ & $80.48(1)$ & $3.077(3)$ \\
$\mathrm{N} 1-\mathrm{H} 1-3 \ldots \mathrm{Cl} 7$ & $1.14(3)$ & $2.976(1)$ & $96.58(2)$ & $3.307(3)$ \\
$\mathrm{N} 3-\mathrm{H} 3-1 \ldots \mathrm{Cl} 6^{(\mathrm{c})}$ & $1.002(2)$ & $2.143(6)$ & $143.49(1)$ & $3.008(2)$ \\
$\mathrm{N} 3-\mathrm{H} 3-1 \ldots \mathrm{Cl} 7^{(\mathrm{d})}$ & $1.002(2)$ & $2.897(1)$ & $107.28(1)$ & $3.335(2)$ \\
$\mathrm{N} 3-\mathrm{H} 3-1 \ldots \mathrm{Cl} 8^{(\mathrm{c})}$ & $1.002(2)$ & $3.056(1)$ & $120.14(1)$ & $3.663(2)$ \\
$\mathrm{N} 3-\mathrm{H} 3-2 \ldots \mathrm{Cl} 3^{(\mathrm{e})}$ & $1.004(2)$ & $2.772(3)$ & $135.38(1)$ & $3.557(2)$ \\
$\mathrm{N} 3-\mathrm{H} 3-2 \ldots \mathrm{Cl} 7^{(\mathrm{d})}$ & $1.004(2)$ & $2.861(1)$ & $109.61(1)$ & $3.335(2)$ \\
$\mathrm{N} 3-\mathrm{H} 3-2 \ldots \mathrm{Cl}^{(\mathrm{d})}$ & $1.004(2)$ & $2.535(1)$ & $134.87(1)$ & $3.321(2)$ \\
\hline
\end{tabular}

Symmetry code: ${ }^{(a)}:(0.5+x, 0,5-y, z) ;^{(b)}:(0,5+x, 0,5+y, z) ;^{(c)}:(1+x, y, 1+z) ;^{(d)}:(0,5+x, 0,5-y, 1+z)$; (e) : $(0,5+\mathrm{x}, 0,5+\mathrm{y}, 1+\mathrm{z})$

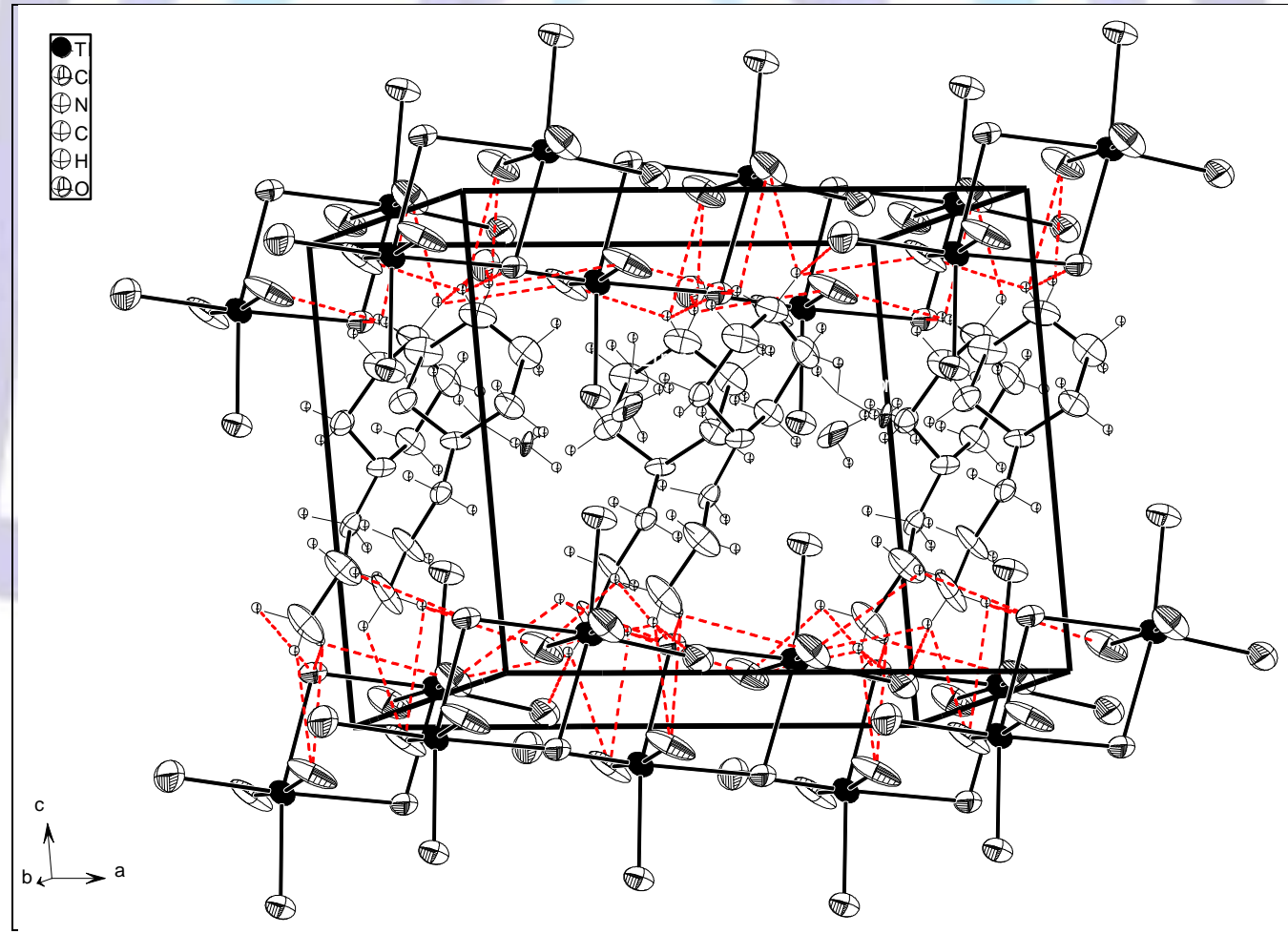

Fig 2: A perspective drawing of $\left[\mathrm{C}_{6} \mathrm{H}_{17} \mathrm{~N}_{3}\right] \mathrm{TICl}_{5} .2 \mathrm{H}_{2} \mathrm{O}$ structure. The broken lines show the hydrogen bonding. 


\section{III.2. Infrared spectroscopy}

As IR spectroscopy is one of the major physical methods of investigation of the molecular structure, we have studied the infrared spectrum of the title compound. IR spectra of this compound have been investigated in the frequency range $400-4000 \mathrm{~cm}^{-1}$. The frequencies of infrared peaks are quoted in Table 5.

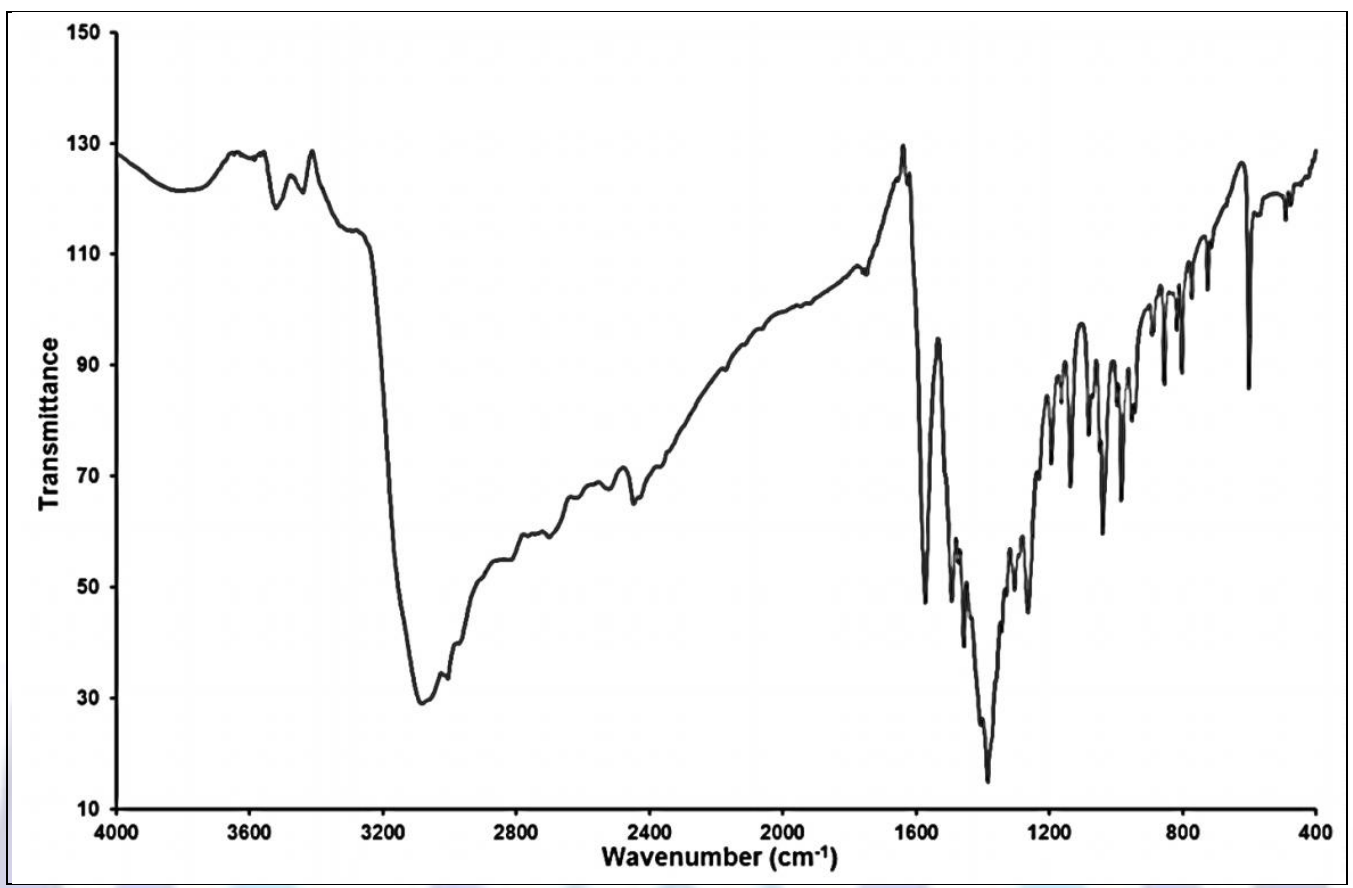

Fig 3: Infrared absorption spectrum of $\left[\mathrm{C}_{6} \mathrm{H}_{17} \mathrm{~N}_{3}\right] \mathrm{TICl}_{5} .2 \mathrm{H}_{2} \mathrm{O}$.

Both absorption bands appearing at $3813 \mathrm{~cm}^{-1}$ and $3520 \mathrm{~cm}^{-1}$ reflect the hydrogen bonded $\mathrm{O}-\mathrm{H}$ stretching frequencies, all the other peaks areas expected for the organic moiety.

In general, arylammonium ions display a strong and broad absorption in the region of $3300-3030 \mathrm{~cm}^{-1} \mathrm{due}$ to $\mathrm{N}-\mathrm{H}$ stretching vibration, whereas $\mathrm{C}-\mathrm{N}$ bending vibration of secondary amine appears at around $1384 \mathrm{~cm}^{-1}[15,16]$ and $\mathrm{C}-\mathrm{C}$ bending vibration appears at $1303 \mathrm{~cm}^{-1}$. All the bands were assigned by comparison with the spectra of organic compounds $[17,18]$.

Table 5. Infrared frequencies $\left(\mathrm{cm}^{-1}\right)$ and band assignment

\begin{tabular}{ll}
\hline $\mathrm{IR}\left(\mathrm{cm}^{-1}\right)$ & Assignment \\
\hline 3800 & $v_{\mathrm{as}}(\mathrm{O}-\mathrm{H})$ \\
3520 & $v_{\mathrm{s}}(\mathrm{O}-\mathrm{H})$ \\
3444 & $v_{\mathrm{as}}\left(\mathrm{NH}_{3}^{+}\right)$ \\
3314 & $v_{\mathrm{as}}\left(\mathrm{NH}_{2}^{+}\right)$ \\
3080 & $v_{\mathrm{s}}\left(\mathrm{NH}_{3}^{+}\right), v_{\mathrm{s}}\left(\mathrm{NH}_{2}^{+}\right)$ \\
2970 & $v_{\mathrm{as}}\left(\mathrm{CH}_{2}\right)$ \\
2818 & $v_{\mathrm{s}}\left(\mathrm{CH}_{2}\right)$ \\
1572 & $\delta_{\mathrm{s}}\left(\mathrm{NH}_{2}^{+}\right), \delta_{\mathrm{as}}\left(\mathrm{NH}_{3}{ }^{+}\right)$ \\
1493 & $\delta_{\mathrm{s}}\left(\mathrm{NH}_{3}^{+}\right), \delta_{\mathrm{a}}\left(\mathrm{CH}_{2}\right)$ aliphatic \\
1475 & $\delta_{\mathrm{s}}\left(\mathrm{NH}_{3}^{+}\right), \delta_{\mathrm{s}} \mathrm{CH}_{2}$ aliphatic \\
1458 & $\delta_{\mathrm{s}}\left(\mathrm{NH}_{3}^{+}\right), \delta_{\mathrm{as}}\left(\mathrm{CH}_{2}\right)$ cyclic \\
1439 & $\delta_{\mathrm{as}}\left(\mathrm{CH}_{2}\right)$ cyclic \\
1408 & $\delta\left(\mathrm{CNH}^{+}, \delta\left(\mathrm{CCH}^{2}, \delta(\mathrm{NCH})\right.\right.$ \\
\hline
\end{tabular}


1384

1344

1330

1304

1292

1266

1233

1195

1164

1136

1082

1070

1051

1039

998

953

942

854

818

800

772

602

576
$v(\mathrm{C}-\mathrm{N})$ secondary amine, $\delta(\mathrm{CNH}), \delta(\mathrm{CCH}), \delta(\mathrm{NCH})$

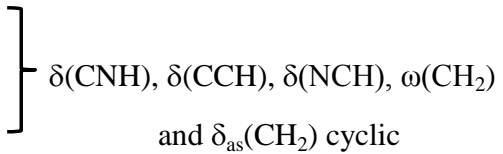

\}

$\mathrm{T}\left(\mathrm{CH}_{2}\right)$

$\rho\left(\mathrm{NH}_{3}{ }^{+}\right)$

$v_{\mathrm{a}}(\mathrm{C}-\mathrm{N}), \mathrm{T}\left(\mathrm{CH}_{2}\right)$ and $\rho\left(\mathrm{NH}_{3}{ }^{+}\right)$

$v_{\mathrm{a}}(\mathrm{C}-\mathrm{C}), \rho\left(\mathrm{NH}_{2}{ }^{+}\right)$and $\omega\left(\mathrm{CH}_{2}\right) \delta(\mathrm{C}-\mathrm{H})$ cyclic in plane

$v_{\mathrm{a}}(\mathrm{C}-\mathrm{C})$

$v_{\mathrm{a}}(\mathrm{C}-\mathrm{N})$

$\delta(\mathrm{C}-\mathrm{H})$ out of plane; $v(\mathrm{C}-\mathrm{N})$ primary amine

$\rho\left(\mathrm{NH}_{3}\right)$ and $\mathrm{CH}$ bending

$\rho\left(\mathrm{NH}_{3}\right), \mathrm{r}\left(\mathrm{NH}_{3}\right)$

$\rho\left(\mathrm{CH}_{2}\right)$

$\left\lceil\rho\left(\mathrm{CH}_{2}\right)\right.$

$\omega\left(\mathrm{NH}_{3}^{+}\right)$

Jv(C-C-N)

\section{III.3. Calorimetric study}

DSC experiments were performed on heating the 1 (2-ammonium-ethyl) piperaziniumpentachlorothallate (III) dihydrate samples from $193 \mathrm{~K}$ to $373 \mathrm{~K}$. The thermal analysis results are reported in figure 4 . The thermogram reveals one endothermic peak at $\mathrm{T}=320 \mathrm{~K}$. The calculated transition enthalpy for this transition is $\Delta \mathrm{H}=200.14 \mathrm{~J}^{\mathrm{mol}}{ }^{-1}$. This transition was confirmed by dielectric permittivity and conductivity measurements at different frequencies and temperatures. 


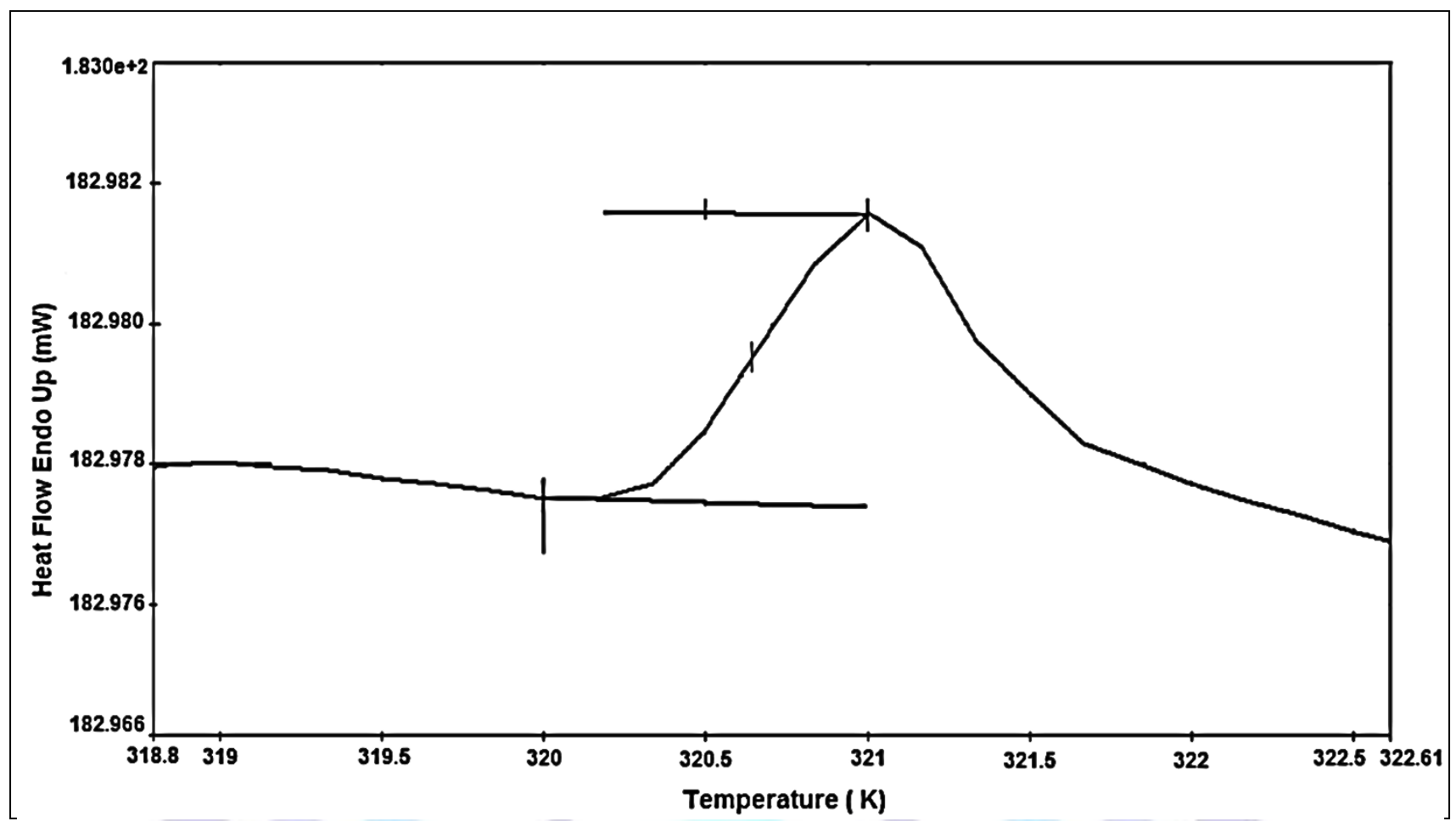

Fig 4.: Differential scanning calorimetry curve of $\left[\mathrm{C}_{6} \mathrm{H}_{17} \mathrm{~N}_{3}\right] \mathrm{TICl}_{5} .2 \mathrm{H}_{2} \mathrm{O}$.

\section{III.4. Electrical study}

The study of dielectric properties is an important source of valuable information about conduction processes and, in order to give more information on the crystal dynamics, we have undertaken a dielectric study between 298 and $413 \mathrm{~K}$ in the frequency range of $1 \mathrm{~Hz}-1 \mathrm{MHz}$.

\section{Impedance spectroscopy}

Complex impedance spectra $Z^{\prime \prime}$ vs. $Z^{\prime} ;\left[Z^{\prime \prime}=f\left(Z^{\prime}\right)\right]$ recorded at various temperatures are presented in Figure 8 . As the temperature increases, the semicircles move to a lower value of resistance. So, the complex impedance spectrum shows that the title compound follows the Cole-Cole law. 


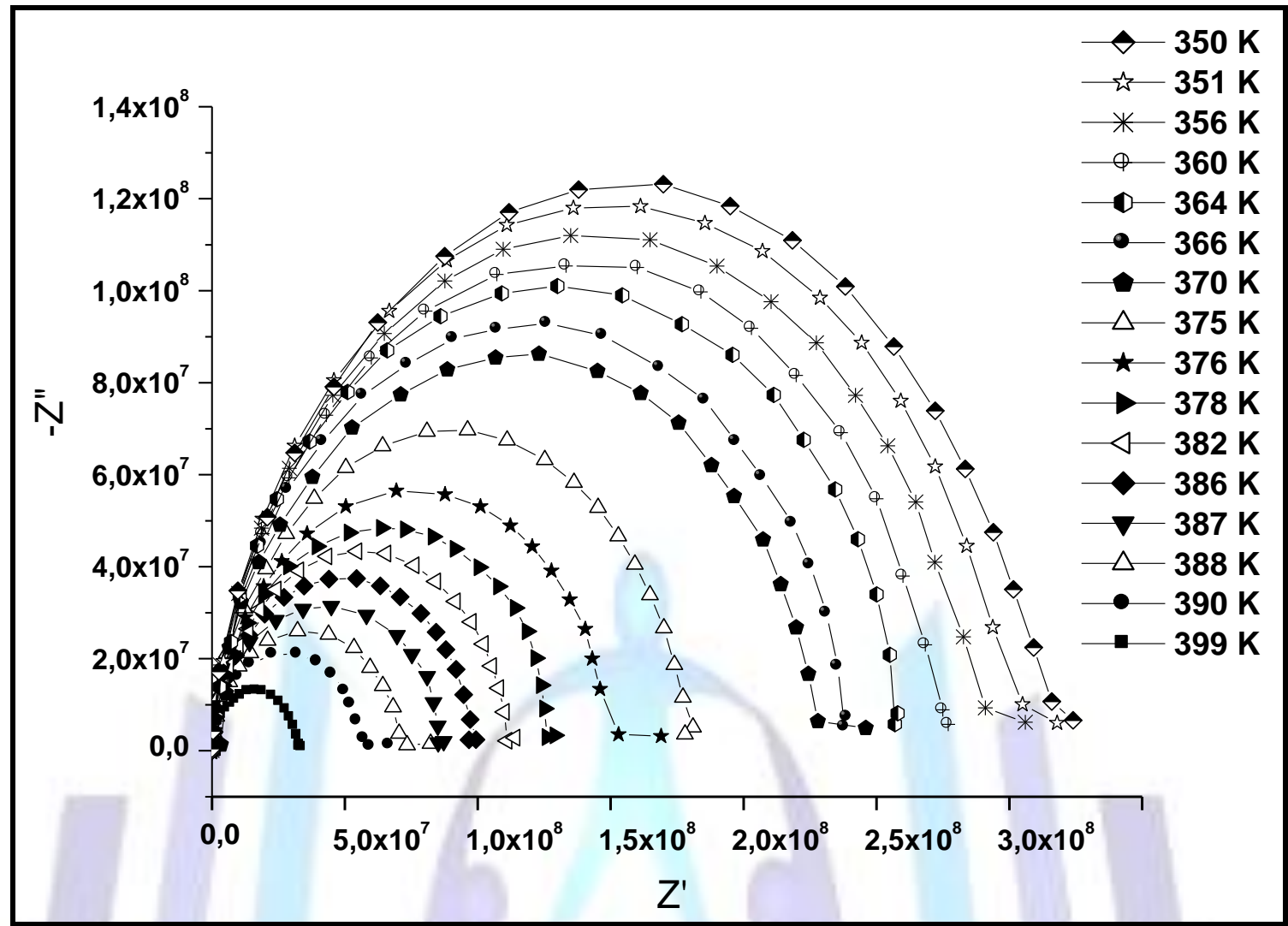

Fig 8: Complex impedance diagrams (-Z' versus $\left.Z^{\prime}\right)$ for $\left[\mathrm{C}_{6} \mathrm{H}_{15} \mathrm{~N}_{3}\right] \mathrm{TICl}_{5 .} 2 \mathrm{H}_{2} \mathrm{O}$ at various temperatures.

The following relations were used forevaluating the various quantities. Realpart $(Z)$ and imaginarypart $\left(Z^{\prime \prime}\right)$ of impedance were directly measured from thebridge.

The complex dielectric constant:

$$
\mathrm{Z}^{*}=\frac{1}{\mathrm{Y}^{*}}=\frac{1}{j \omega \mathrm{C}_{0} \varepsilon^{*}}
$$

Where $\varepsilon^{*}=\varepsilon_{\mathrm{r}}^{\mathrm{j}}-\mathrm{j} \varepsilon_{\mathrm{r}}$

The real part of the dielectricconstant,

$\varepsilon_{\mathrm{r}}^{\prime}=\frac{Z^{\prime \prime}}{\omega \mathrm{C}_{0}\left(Z^{\prime 2}+Z^{\prime 2}\right)}$

The imaginary part of the dielectric constant,

$\varepsilon_{\mathrm{r}}^{\prime \prime}=\frac{Z^{\prime}}{\omega \mathrm{C}_{0}\left(Z^{\prime 2}+Z^{\prime 2}\right)}$

With $\mathrm{C}_{0}=\frac{\varepsilon_{0} S}{e}, \varepsilon_{0}=(1 / 36 \pi) 10^{-9}$ F.m $\mathrm{m}^{-1}$ permittivityof the vacuum.

$S$ and $\mathrm{e}$ represent respectively the surface and the thickness of the title compound. The dielectric loss or dissipation factor $\operatorname{tg} \delta$ is the ratio $\varepsilon_{r}^{\prime \prime} / \varepsilon_{r}^{\prime}$. The temperature dependence of the real $\left(\varepsilon_{r}^{\prime}\right)$, imaginary $\left(\varepsilon_{r}^{\prime \prime}\right)$ of the dielectric permittivity and the dissipation factor (tan $\delta$ ) in the $1 \mathrm{~Hz}-1 \mathrm{MHz}$ range of $\left[\mathrm{C}_{6} \mathrm{H}_{15} \mathrm{~N}_{3}\right] \mathrm{TICl}_{5} .2 \mathrm{H}_{2} \mathrm{O}$ at different frequencies is shown in figures 5,6 and 7 . These curves show one anomaly at about $320 \mathrm{~K}$. As can be clearly seen, there is significant dispersion of real dielectric permittivity attributed to the phase transition detected by DSC.

The maximum of the permittivity is displaced tohigher temperaturesupon with increasing frequency; which is in agreement with the presence of conductivity relaxation.

From the qualitative analysis of $\varepsilon_{\mathrm{r}}^{\prime}$, two consecutive steps can be observed: 
- The dielectric response shows anomaly around $\mathrm{T}=320 \mathrm{~K}$ and a very large increase in permittivity above this transition. This behaviour confirms the results obtained by the DSC method.

- The permittivity $\varepsilon_{r}^{\prime}$ around T considerably increases as frequency decreases. This is in agreement with the large conductivity present in this material.

Consequently, the real part of permittivity can be considered as the summation of two contributions: the first presents the lattice response due to permanent dipole orientation, and the second is attributed to the conductivity phenomenon related to the organic cation containing $\pi$-electrons systems asymmetrized by electron donor and/or acceptor substitutes [38].

The values of dissipation factor are relatively large, in agreement with the important contribution of conductivity in this material, so thetransition is characterized by a maximum of $\varepsilon$ ' and $\varepsilon^{\prime \prime}$ at $320 \mathrm{~K}$ corresponding to a maximum of tan $\delta$, This dielectric behavior rules out the existence of a ferroelectric phase at high temperature and this transition is manifested by a strong jump in the conductivity plot. So, by increasing the temperature, as a consequence of $\mathrm{Cl}$ atoms disordering, the reorientation of $\mathrm{NH}_{3}{ }^{+}$and $\mathrm{NH}_{2}{ }^{+}$ions becomes more exited, which contributes to the high conductivity of the material [37]. This freezing is usually associated with changes in the hydrogen bonding scheme between the organic cations and the anionic groups which results in significant distortions of the latter [19-20].

This feedback between the two structural elements is responsible for the complex transition situation in this family of compounds and provides the opportunity to tailor the transition behavior and physical properties through synthesis.

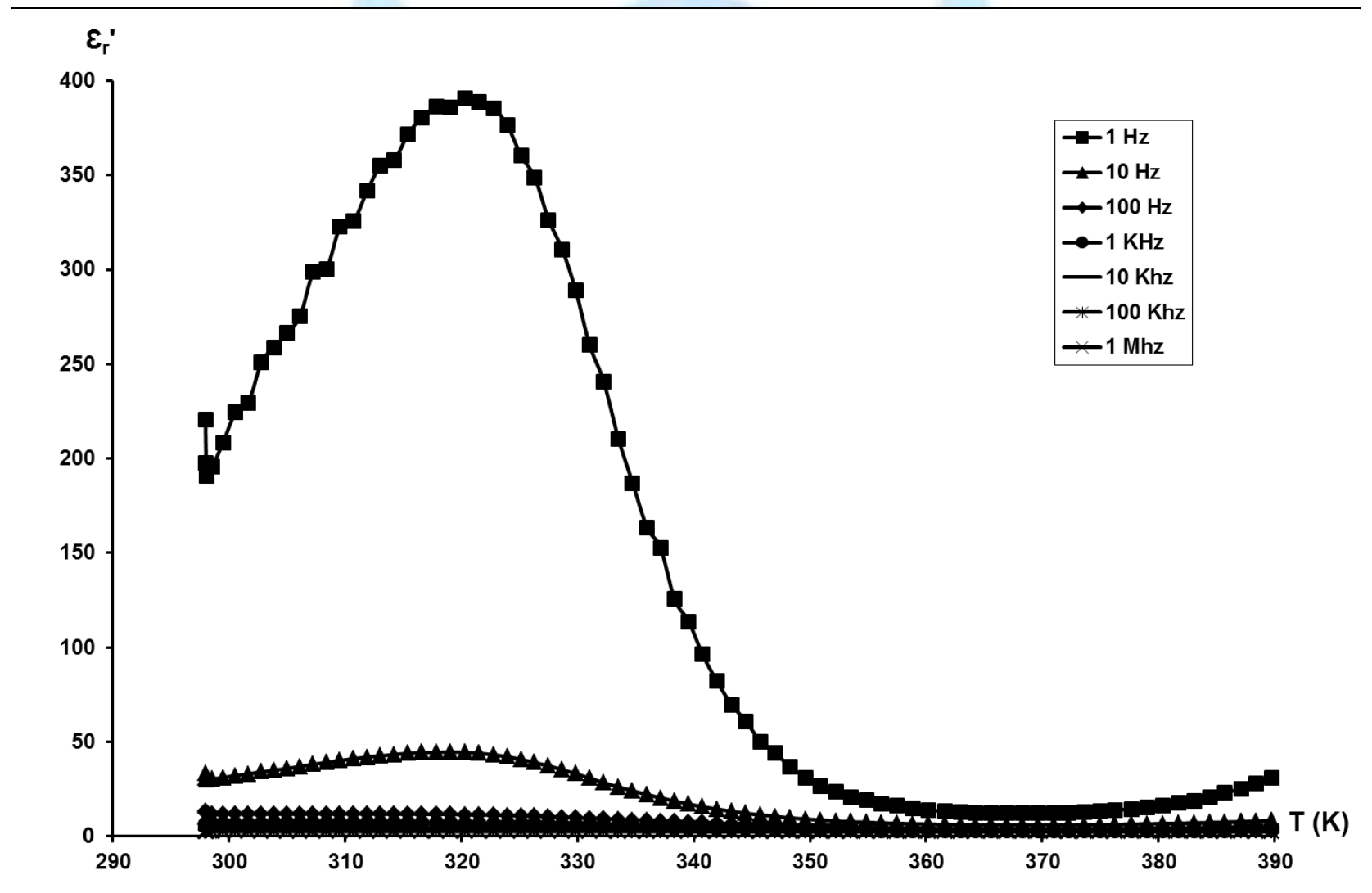

Fig 5: Temperature dependence of $\varepsilon_{\mathrm{r}}$ ' for different frequencies for $\left[\mathrm{C}_{6} \mathrm{H}_{15} \mathrm{~N}_{3}\right] \mathrm{TICl}_{5} .2 \mathrm{H}_{2} \mathrm{O}$ 


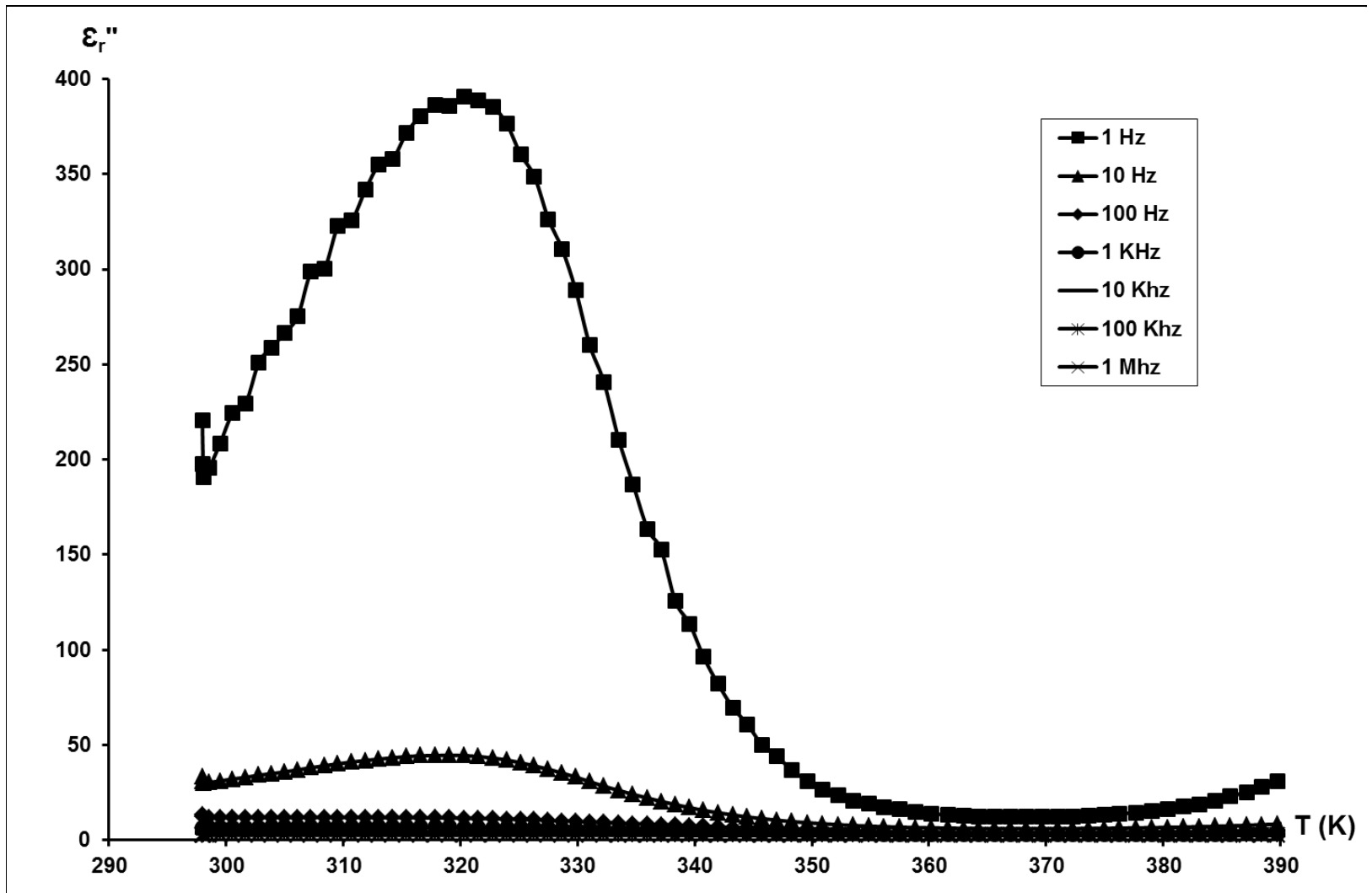

Fig 6: Temperature dependence of $\varepsilon_{\mathrm{r}}$ "for different frequencies for $\left[\mathrm{C}_{6} \mathrm{H}_{15} \mathrm{~N}_{3}\right] \mathrm{TICl}_{5} .2 \mathrm{H}_{2} \mathrm{O}$

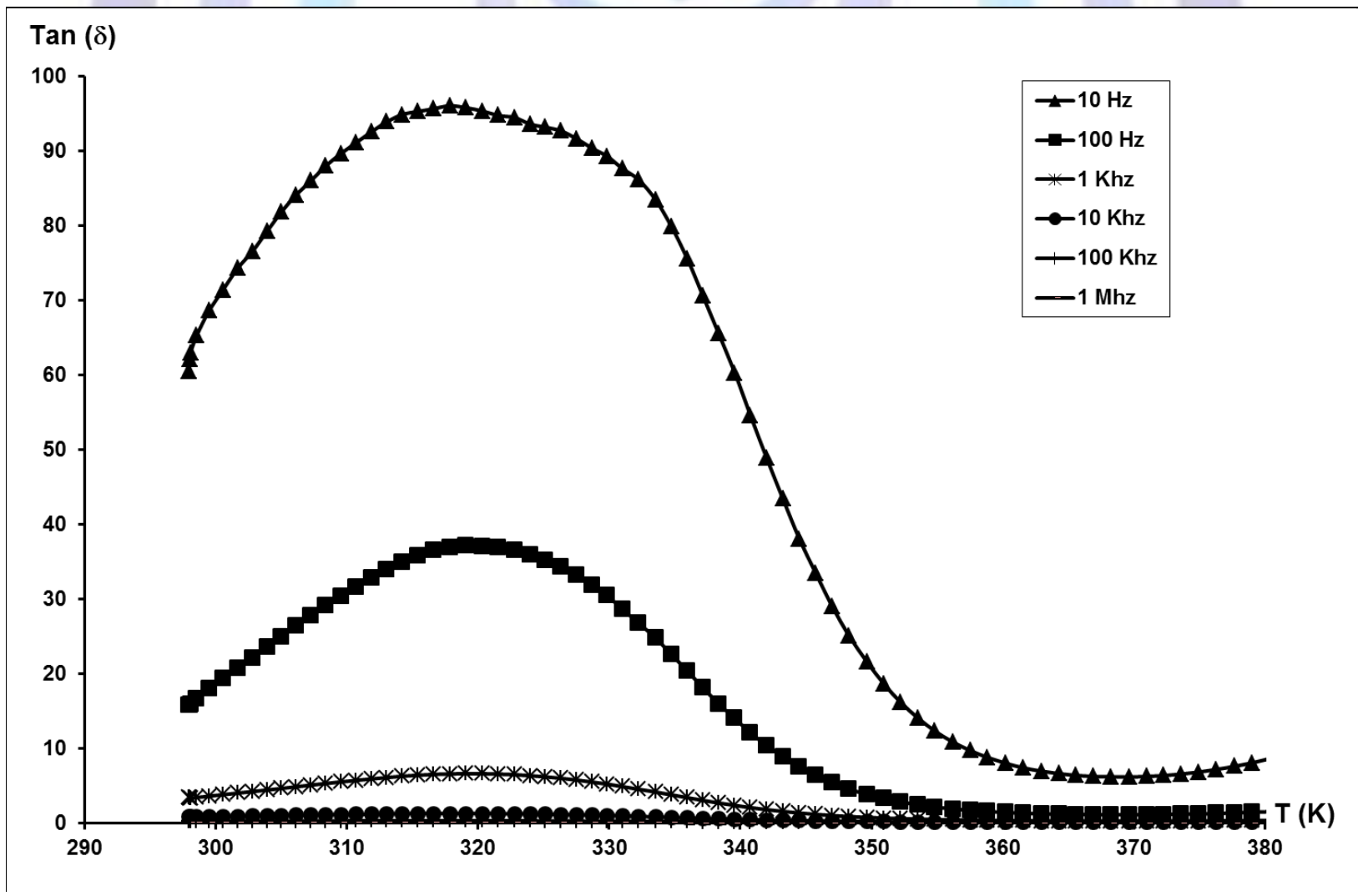

Fig 7: Temperature variation of $\tan \delta$ for $\left[\mathrm{C}_{6} \mathrm{H}_{15} \mathrm{~N}_{3}\right] \mathrm{TICl}_{5} .2 \mathrm{H}_{2} \mathrm{O}$. 
In order to understand the conduction phenomena, we used Arrhenius modeling equation: $\sigma \mathrm{T}=\mathrm{Aexp}\left(-\mathrm{Ea} / \mathrm{k}_{\beta} \mathrm{T}\right)$, where Ea is the activation energy, $\mathrm{A}$ is the pre-exponential factor, $\mathrm{kB}$ is the Boltzmann constant, and $\mathrm{T}$ is the temperature.

The thermal evolution of the specific conductivity $(\log (\sigma T)$ versus $(1000 / T)$ of the 1-(2-ammonium-ethyl) piperaziniumpentachlorothallate (III) is shown in Figure 9 indicating an Arrhenius-type behavior. In the 298-413 K temperature range, the conductivity plot exhibits one anomaly at $320 \mathrm{~K}$. Consequently, the diagram presents two regions. The first region between 298 and $320 \mathrm{~K}$ and the second part of the conductivity curve between 320 and $413 \mathrm{~K}$. The conductivity evolution in these regions obey the Arrhenius law.

In comparison with studied thallium (III) compounds [9, 21], this anomaly probably corresponds to a structural phase transition, which transforms our solid solution from phase I to phase II. The activation energy values determined in the two regions I and II are respectively equal to $0.088 \mathrm{eV}$ and $0.416 \mathrm{eV}$. The difference can be due to the high displacement of the ammonium proton.

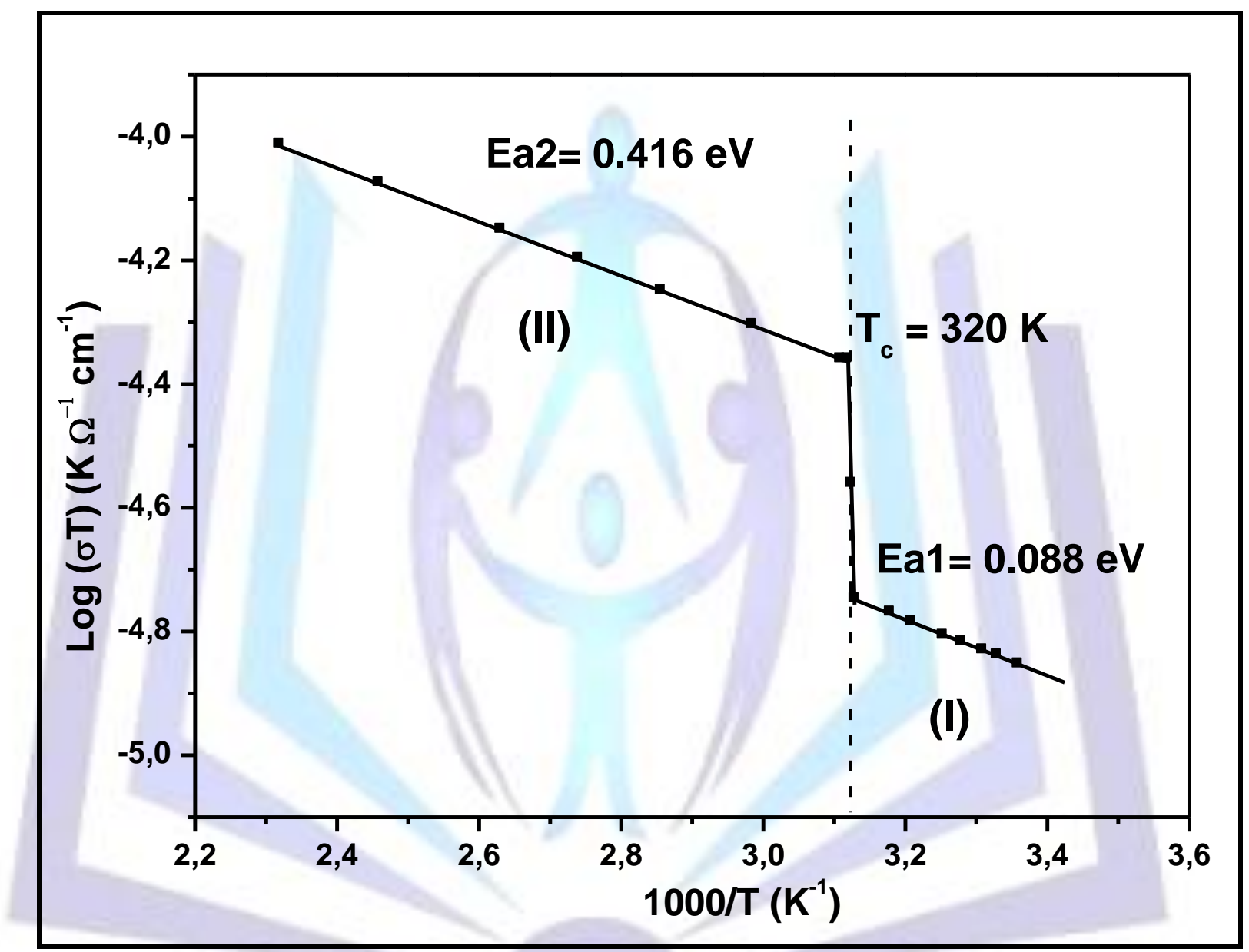

Fig 9: Conductivity plots $\log 10(\sigma T)=f(1000 / T)$ for $\left[\mathrm{C}_{6} \mathrm{H}_{15} \mathrm{~N}_{3}\right] \mathrm{TICl}_{5} .2 \mathrm{H}_{2} \mathrm{O}$.

Crystallographic studies show that this material presents a noncentrosymmetric space group at room temperature which is in agreement with our last deduction. This interpretation remains to be confirmed by pyroelectric and dielectric hysteresis measurements on single crystals. This anomaly is characterized by a sharp increase in the conductivity values, the conductivity increases from $\sigma=4.70 .10^{-8} \mathrm{~S} . \mathrm{cm}^{-1} \cdot \mathrm{K}^{-1}$ at $298 \mathrm{Kto} \sigma=2.26 \cdot 10^{-7} \mathrm{~S} . \mathrm{cm}^{-1} \cdot \mathrm{K}^{-1}$ at $413 \mathrm{~K}$. The sudden variation of the conductivity at $320 \mathrm{~K}$ marks the transition.

- To more disordered state which might be correlated with changes in the orientation of molecular groups as $\left[\mathrm{C}_{6} \mathrm{H}_{15} \mathrm{~N}_{3}\right]$ or $\mathrm{TICl}_{5}$; conduction.

- And to the high dynamical disorder of $\mathrm{NH}_{3}$ proton in the $\mathrm{N}-\mathrm{H}$. . Cl hydrogen bond which leads to fast proton

The conductivity here is considered to be induced by the reorientation of $\left[\mathrm{C}_{6} \mathrm{H}_{15} \mathrm{~N}_{3}\right]^{+}$cations. By increasing the temperature, as consequence of the disordering of $\mathrm{H}$ atoms the reorientation of $\mathrm{NH}_{2}{ }^{+}$and $\mathrm{NH}_{3}{ }^{+}$ions becomes more excited which contribute to high conductivity of the material $[22,23]$. 


\section{Conclusion}

The 1(2-ammonium-ethyl) piperaziniumpentachlorothallate (III) dihydrate belongs to the monoclinic system with $\mathrm{Cm}$ space group. The structure of this compound consists of $\left[\mathrm{C}_{6} \mathrm{H}_{17} \mathrm{~N}_{3}\right]^{2+}$ cations and a $\left[\mathrm{Tl}_{2} \mathrm{Cl}_{10}\right]^{4-}$ dimmers. These dimmers are themselves interconnected by means of the $\mathrm{N}-\mathrm{H}---\mathrm{Cl}$ hydrogen bonds.

This study has shown that the $\left[\mathrm{C}_{6} \mathrm{H}_{15} \mathrm{~N}_{3}\right] \mathrm{TICl}_{5} .2 \mathrm{H}_{2} \mathrm{O}$ crystal undergoes a second phase transition as a function of temperature as determinated by differential scanning calorimetry, and dielectric measurement. We note the appearance of the $(\mathrm{I} \rightarrow \mathrm{II})$ phase transition at $\mathrm{T}=320 \mathrm{~K}$, which is of the order-disorder type. This can be explained by the conductivity phenomenon related to the organic aromatic cation containing $\pi$-electrons systems asymmetrized by electron donor and/ or acceptor substitutes.

Additional studies on the nature of the phase transition (NQR and crystal structure at high temperature) are under way and will give more information on the nature of the structural phase transition.

\section{ACKNOWLEDGEMENTS}

This work was supported by the Minister Education and Research of Tunisia.

\section{REFERENCES}

[1] T. Spiro, Inorg. Chem. 4 (1965) 731-738

[2] J. Hoard, I.J. Goldstein, Chem. Phys. 3 (1935) 199-202.

[3] A. Linden, A. Petridis, B.D. James, Acta Crystallogr. C 58 (2002)53-55.

[4] A. Linden, B.D. James, Acta Crystallogr. C 58 (2002) 439-440.

[5] A. Linden, K.W. Nugent, A. Petridis, B.D. James, Inorg. Chim.Acta 285 (1999) 122-128.

[6] A. Linden, M.A. James, M.B. Millikan, L.M. Kivligghon, A. Petridis,B.D. James, Inorg. Chim. Acta 284 (1999) $215-222$.

[7] A. Linden, A. Petridis, B.D. James, Inorg. Chim. Acta 332 (2002) 61-71.

[8] R.A. Walton, Inorg. Chem. 7 (1968) 640-648.

[9] U. Geiser, J.A. Schlueter, A.M. Kini, A. Achenbach, A.S. Komosa,

J.M. Williams, ActaCrystallogr. C 52 (1996) 159-162

[10] G. Charlot, Chimie Analytique Quantitative, vol. 2, Masson et Cie, Paris, 1974

[11] G.M. Sheldrick, Program for Crystal Structure Determination; SHELXS-86 (1990).

[12] G.M. Sheldrick, Program for Crystal Structure Determination; SHELXL-97 (1997).

[13] A. Linden, B.D. James, Acta Cryst. C58 (2002) 439-440.

[14] M. Abdi, F. Zouari, S. Chaabouni, Z. Elaoud, A. Ben Salah, Phase Transit. 76 (2003) 723-731.

[15] Misra SCK, Chandra S. Indian J Chem 1994;33A:583-594.

[16] Silverstein RM, Webster FX. Spectroscopic identification oforganic compounds. 6th ed. Singapore: John Wiley \&Sons, Inc; 2002.

[17] A. Margareta, G.H. Mateescu, Infra RedSpectroscopy, WileyInterscience, New York, 1972.

[18] L.J. Bellamy, The Infrared Spectra of Complex Molecules, Chapman and Hall, London, 1995.

[19] R. Jakubas, L. Sobczyk, Phase Transit. 20 (1990) 163-193.

[20] R. Jakubas, G. Bator, Z. Ciunik, Ferroelectrics 295 (2003) 3-8.

[21] R.A. Walton, Inorg. Chem. 7 (1968) 640-648.

[22] A. Kabadou, S. Walha, M. Mnif, R. Ben Hassen, A. Ben Salah, Solid State lonics 122 (1999) 263-269.

[23] A. Kabadou, R. Ben Hassen, A. Ben Salah, T. Jouini, Status Solidi 208 (1998) 387-395. 